\title{
Eco-Friendly Yield and Greenhouse Gas Emissions as Affected by Fertilization Type in a Tropical Smallholder Rice System, Ghana
}

\author{
Kofi Konadu Boateng ${ }^{1, *}$, George Yaw Obeng ${ }^{2}$ and Ebenezer Mensah ${ }^{1}$ \\ 1 Department of Agricultural and Biosystems Engineering, College of Engineering, Kwame Nkrumah \\ University of Science and Technology, P.O. Box Up 1279, Kumasi, Ghana; ebenmensah@gmail.com \\ 2 Department of Mechanical Engineering, College of Engineering, Kwame Nkrumah University of Science and \\ Technology, P.O. Box Up 1279, Kumasi, Ghana; gyobeng.coe@knust.edu.gh \\ * Correspondence: edkoboat@hotmail.com; Tel.: +233-24-991-851
}

Received: 26 October 2020; Accepted: 24 November 2020; Published: 8 December 2020

\begin{abstract}
Data on greenhouse gas emission levels associated with fertilization applied in smallholder paddy rice farms in Ghana are scanty. The current study investigated fertilization types to determine their eco-friendliness on yield, Global Warming Potential (GWP) and Greenhouse Gas Intensity (GHGI) in a major rice season in the forest zone of Ghana. In total, five treatments were studied viz Farmer Practice (BAU); Biochar + Farmer Practice (BAU + BIO); Poultry Manure + Farmer Practice $(\mathrm{BAU}+\mathrm{M})$; Biochar + Poultry Manure + Farmer Practice $(\mathrm{BAU}+\mathrm{BIO}+\mathrm{M})$; and Control $(\mathrm{CT})$. Fluxes of methane $\left(\mathrm{CH}_{4}\right)$ and nitrous oxide $\left(\mathrm{N}_{2} \mathrm{O}\right)$ were measured using a static chamber-gas chromatography method. $\mathrm{N}_{2} \mathrm{O}$ emissions at the end of the growing season were significantly different across treatments. $\mathrm{BAU}+\mathrm{BIO}+\mathrm{M}$ had highest $\mathrm{N}_{2} \mathrm{O}$ flux mean of $0.38 \mathrm{kgNha}^{-1}$ day $^{-1}( \pm 0.18)$. BAU $+\mathrm{M}$ had the second highest $\mathrm{N}_{2} \mathrm{O}$ flux of $0.27 \mathrm{kgNha}^{-1} \mathrm{day}^{-1}( \pm 0.08)$, but was not significantly different from BAU at $p>0.05$. BAU+BIO recorded $0.20 \mathrm{kgNha}^{-1} \mathrm{day}^{-1}( \pm 0.12)$, lower and significantly different from BAU, $\mathrm{BAU}+\mathrm{M}$ and $\mathrm{BAU}+\mathrm{BIO}+\mathrm{M} . \mathrm{CH}_{4}$ emissions across treatments were not significantly different. However, highest $\mathrm{CH}_{4}$ flux was recorded in BAU+BIO at $4.76 \mathrm{kgCH}_{4} \mathrm{ha}^{-1} \mathrm{day}^{-1}( \pm 4.87)$. GWP based on seasonal cumulative GHG emissions among treatments ranged from $5099.16( \pm 6878.43)$ to 20894.58 $( \pm 19645.04)$ for $\mathrm{CH}_{4}$ and $756.28( \pm 763.44)$ to $27201.54( \pm 9223.51) \mathrm{kgCO}_{2}$ eqha $^{-1}$ Season $^{-1}$ for $\mathrm{N}_{2} \mathrm{O}$. The treatment with significantly higher yield and low emissions was BAU + M with a GHGI of 4.38 $( \pm 1.90) \mathrm{kgCO}_{2} \mathrm{eqkg}^{-1}$.
\end{abstract}

Keywords: paddy rice; greenhouse gas emissions; global warming potential (GWP); greenhouse gas intensity (GHGI); methane $\left(\mathrm{CH}_{4}\right)$; nitrous oxide $\left(\mathrm{N}_{2} \mathrm{O}\right)$; eco-friendly yield

\section{Introduction}

Agricultural systems represent a key source of Greenhouse Gas Emissions (GHGE) and contribute at least $12 \%$ to global anthropogenic emissions [1-3]. Paddy rice production forms a significant percentage of emissions that are generated from agricultural production systems and in Sub-Saharan African (SSA) agricultural systems have been cited as an area where GHGE are expected to grow due to a growing population and the need to grow more food to feed the increase in population $[4,5]$. Rice remains an important staple food for millions of households in SSA including Ghana where local production deficit has necessitated an intensification of local rice production. However, the production of rice is an important source of potent greenhouse gases including methane and nitrous oxide.

Emissions from paddy rice production are principally methane and nitrous oxide due to waterlogged field conditions (anoxic environment) and nitrogen fertilizer usage, respectively. Methane emissions from rice production alone accounts for an estimated $11 \%$ of anthropogenic 
emissions [5]. Over the past decade, a significant percentage (94\%) of emissions from paddy rice production has emanated from developing countries. Asia leads with $90 \%$ of these emissions with an annual growth rate of $0.4-0.7 \%$ per year. The largest growth of emissions was recorded in Africa at $2.7 \%$ annually [6]. This growth in emissions is expected to increase as a response to high demand for rice to feed the growing population. There is therefore the need to sustainably intensify rice cropping systems to increase yields while reducing associated emissions [7]. The utilization of local materials, including Biochar from farm crop residues and poultry manure, has been touted to have the potential to provide a sustainable and cheap alternative to the conventional use of inorganic fertilization options in rice and other crop production [8-16].

An increasing demand on food to meet a growing population has meant a growing pressure on soils to sustain food production. Soil amendments, both organic and inorganic, has been extensively used to replenish lost soil nutrients to sustain production. Land management practices for rice productivity have been a key focus of research due to the opportunities that are available for substantial carbon sequestration and other GHG mitigation [17]. Paddy rice cultivation requires soil fertilization to ensure yield security and this practice is a key management factor that affects GHG emissions $[11,18,19]$. Various works that have been done on the effect of soil amendments on emissions confirm that management practices including soil amendment regimes can be efficiently managed to reduce emissions [20-22].

A quantitative review and analysis of fertilizer management practices on GHG emissions from rice cultivation systems by Linquist et al. [23] concluded that there is a positive correlation between fertilizer management practices and GHG emissions. The study suggested the need to investigate options for combining mitigation practices and also to determine the economic viability of these practices. Sampanpanish [24], studied the impact of organic and inorganic fertilizers on the emission levels of carbon dioxide $\left(\mathrm{CO}_{2}\right)$, methane $\left(\mathrm{CH}_{4}\right)$, and nitrous oxide $\left(\mathrm{N}_{2} \mathrm{O}\right)$. The results of the study indicated a higher rate of emissions from chemical fertilizers when compared with emissions from organic fertilizers and therefore the use of organic fertilizers was recommended.

The objective of this study was to investigate the influence of organic and inorganic fertilization type on the yield, GWP, and GHGI of smallholder paddy rice firms in Ghana. We report that the use of organic soil amendment (poultry manure and Biochar) as components of conventional inorganic fertilizer use has a positive yield effect and also delivered the lowest emission per kilogram yield of rice (eco-friendly yield). In this paper, yields with low emissions per kilogram of yield are defined as eco-friendly.

\section{Materials and Methods}

\subsection{Study Area and Experimental Design}

The site selected for this research work was Nobewam $\left(6.6237^{\circ} \mathrm{N}, 1.2940^{\circ} \mathrm{W}\right)$, a predominantly smallholder rice producing community in the Juaben Municipality of the Ashanti Region of Ghana. The community lies in the semideciduous forest zone of Ghana with diverse flora and fauna. The topography of the area is generally undulating, dissected by plains and slopes with heights ranging between $240 \mathrm{~m}$ and $300 \mathrm{~m}$ above sea level. The geology of the municipality is Precambrian rocks of the Birimian and Tarkwaian formations that are generally suitable for agriculture. The soils include the associations of the Kumasi-Offin, Bomso-Offin, Kobeda-Esshiem-Oda, Bekwai-Oda Compound, and Juaso-Mawso Compounds. The municipality experiences a bimodal rainfall pattern [25]. The weather data of the study area (mean precipitation and temperature) for 2019 from the nearest weather station are presented in Figure 1. 


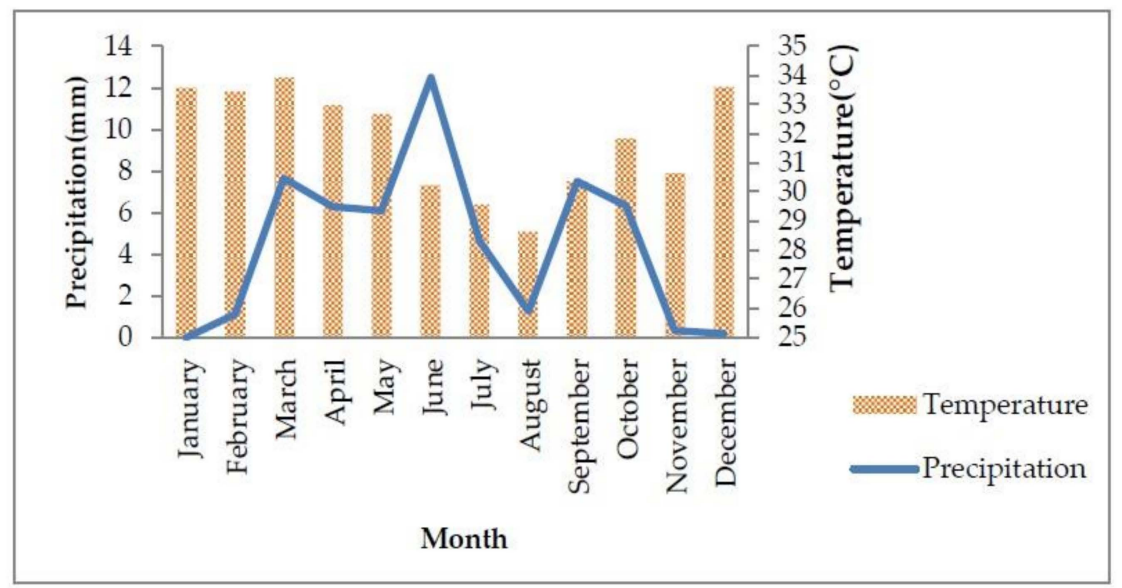

Figure 1. 2019 mean precipitation and temperature of study area.

The experiment was arranged as a randomized block design with 4 replications (Table 1 ) and the plot size was $2 \mathrm{~m} \times 3 \mathrm{~m}$ for all treatments (Figure 2).

Table 1. Field design of study.

\begin{tabular}{cccc}
\hline Block $\mathbf{1}$ & Block $\mathbf{2}$ & Block 3 & Block 4 \\
\hline $\mathrm{T} 3$ & $\mathrm{~T} 1$ & $\mathrm{~T} 2$ & $\mathrm{~T} 1$ \\
$\mathrm{CT}$ & $\mathrm{T} 2$ & $\mathrm{~T} 1$ & $\mathrm{CT}$ \\
$\mathrm{T} 4$ & $\mathrm{~T} 3$ & $\mathrm{~T} 3$ & $\mathrm{~T} 2$ \\
$\mathrm{~T} 2$ & $\mathrm{~T} 4$ & $\mathrm{CT}$ & $\mathrm{T} 4$ \\
$\mathrm{~T} 1$ & $\mathrm{CT}$ & $\mathrm{T} 4$ & $\mathrm{~T} 3$ \\
\hline
\end{tabular}

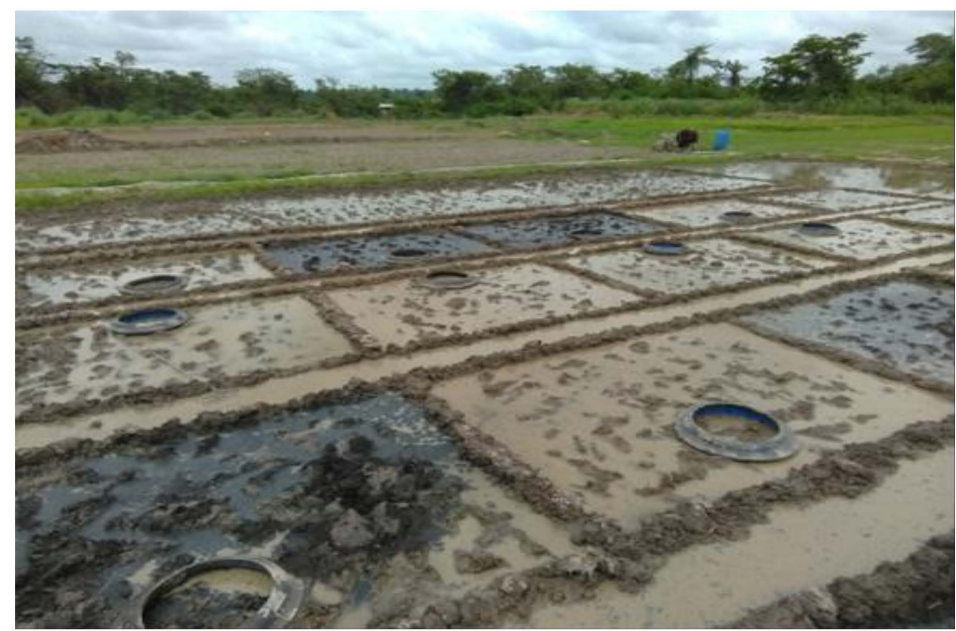

Figure 2. Field arrangement of treatment plots.

\subsection{Fertilisation Types}

In total, 5 soil fertilization treatments with 4 replicates were studied to measure their effect on emissions and yield of rice. The treatments were as follows:

1. Farmer Practice (BAU): This treatment represented the conventional means by which smallholder farmers cultivated rice in the study area. It was designated as Business as Usual (BAU) and the fertilizer application rate under this treatment was $300 \mathrm{kgha}^{-1}$ of NPK as base and $50 \mathrm{kgha}^{-1}$ urea $(46 \% \mathrm{~N})$ top-up.

2. Biochar $(\mathrm{Bio})+$ Farmer Practice $(\mathrm{BAU}+\mathrm{Bio})$ : the treatment represented Biochar and BAU soil amendment. A locally made ESLA stove made from a used lube barrel was used to char the 
rice straw under anoxic conditions. Biochar was applied at 28,000 $\mathrm{kg}(28 \mathrm{t})$ per hectare. In rice production, 28 tha $^{-1}$ and 48 tha $^{-1}$ represents $50 \%$ and $100 \%$ of rice straw produced in a single season, respectively. These two rates represent low and high amendment rates. An assumption was therefore made that, should a rice farmer convert at least $50 \%$ of his straw into Biochar and incorporate it on his farm, what will the effect be on yield and GHG emissions.

3. Poultry Manure $(M)+$ Farmer Practice $(B A U+M)$ : For poultry manure, 1 tha $^{-1}, 2$ tha ${ }^{-1}$, and 3 tha ${ }^{-1}$ represents low, medium, and high application rates, respectively. The high application rate of 3 tha $^{-1}$ was selected for the current work.

4. Biochar + Poultry Manure + Farmer Practice $(B A U+B i o+M)$ : The fourth treatment was a combination of farmer practice, poultry manure and Biochar at the same application level as the single treatments.

5. Control treatment (CT): The control treatment did not have any soil amendments.

\subsection{Greenhouse Gas (GHG) Sample Collection}

Samples were collected using the static chamber method. The chamber and bases were designed and constructed according to the guidelines for measuring $\mathrm{CH}_{4}$ and $\mathrm{N}_{2} \mathrm{O}$ emissions from rice paddies by a manually operated closed chamber [26]. A polyvinyl chloride (PVC) bin (height $=72 \mathrm{~cm}$, diameter $=53 \mathrm{~cm}$ ) was converted to serve as the chamber. The choice of the bin for the chamber was based on its inertness to the target gases, lightweight, and ability to withstand breakage. The height was also able to accommodate matured rice plants without damaging it during sampling. The exterior of the chamber was coated white to prevent the effect of solar radiation. A sampling port fitted with a tube was made on the side of the chamber to collect gas samples. The tube was fitted to prevent artificial $\mathrm{CH}_{4}$ ebullition when the chamber was mounted on the base during sampling. On top of the chamber were two additional ports, one to allow for chamber temperature measurement and the other to serve as a vent to prevent drastic changes in inside air pressure during chamber deployment [11]. Samples collection began 2 weeks before transplanting up until 2 weeks after harvesting. Sampling was done twice a week between 9 am and $12 \mathrm{pm}$ with an increase in sampling frequency during fertilizer application and raining events. Samples were taken at 0, 10, and 20-time intervals.

\subsection{GHG Sample Analysis}

Analysis of gas samples was conducted using an appropriately fitted Gas Chromatograph-Scion GC456 (Scion Instruments, West Lothian, Scotland) with an electron capture detector (ECD) for $\mathrm{N}_{2} \mathrm{O}$ detection at $350{ }^{\circ} \mathrm{C}$ and a flame ionization detector (FID) for $\mathrm{CH}_{4}$ detection. Prepared samples were auto-injected into the gas chromatograph (GC) with a CTC PAL Combi-XT (CTC Analytics AG, Zwingen, Switzerland). $\mathrm{N}_{2}$ was used as a carrier gas.

\subsection{Flux Estimation and Statistical Analysis}

Using the R statistical software (R version 3.6.1 (5 July 2019), the Revised Hutchison Mosier (HMR) model by Pedersen et al., [27] was used in calculating flux values for each treatment. The HMR model approaches flux estimation by modifying the classic nonlinear model (HM) proposed by Hutchinson and Mosier [28] to take into account horizontal gas transport through the soil or leaks in the chamber. This provides a robust method to analyze both linear and nonlinear data sets, a practical scenario depiction of gas transport inside a mounted static chamber on the field. The HMR model includes methods for automatic detection and analysis of linear data sets and data sets representing no flux. In total, 2 models were used to test for statistical significance as follows:

Model $1<-$ lmer (Parameter $\sim$ Treatments $+(1 \mid$ Reps $)$, data $=$ Flux, REML $=$ FALSE)

Model $2<-$ aov (Parameter $\sim$ Treatments, data $=$ Flux) key: Parameter $=\mathrm{N}_{2} \mathrm{O}$ or $\mathrm{CH}_{4}$.

Model 1 tested for differences in the random factors (Blocks) but indicated nonsignificance in all treatments. Model 2 was used to perform analysis of variance with means separated by Fishers Least 
Significant Difference (LSD) at $p>0.05$. Seasonal cumulative fluxes of $\mathrm{CH}_{4}$ and $\mathrm{N}_{2} \mathrm{O}$ were calculated by successive linear interpolation of estimated emission flux on successive sampling days with the assumption that the emissions followed a linear trend during nonsampling days [29].

\subsection{Global Warming Potential (GWP) and Greenhouse Gas Intensity (GHGI)}

For $\mathrm{CH}_{4}$ and $\mathrm{N}_{2} \mathrm{O}$ in this current work, the following equations were used in determining relevant GWP ( $\mathrm{kgCO}_{2}$-equivalent).

$$
\begin{aligned}
\mathrm{GWP}_{\mathrm{CH} 4} & =\mathrm{C}-\mathrm{CH}_{4} \times 16 / 12 \times 25 \\
\mathrm{GWP}_{\mathrm{N} 2 \mathrm{O}} & =\mathrm{N}-\mathrm{N}_{2} \mathrm{O} \times 44 / 28 \times 298
\end{aligned}
$$

where $\mathrm{C}-\mathrm{CH}_{4}$ and $\mathrm{N}-\mathrm{N}_{2} \mathrm{O}$ are gases fluxes $\left(\mathrm{kgha}^{-1}\right.$ season $\left.{ }^{-1}\right) ; 16 / 12=$ ratio between the molecular mass of $\mathrm{CH}_{4}$ and $\mathrm{C} ; 44 / 28=$ ratio between the molecular mass of $\mathrm{N}_{2} \mathrm{O}$ and $\mathrm{N} ; 25$ is the Global Warming Potential (GWP) of $\mathrm{CH}_{4}$ and 298 of $\mathrm{N}_{2} \mathrm{O}$ [30,31].

Greenhouse Gas Intensity was calculated using the following equation;

$$
\mathrm{GHGI}=\mathrm{GWP} / \mathrm{Y}
$$

where GWP is the global warming potential of $\mathrm{CH}_{4}$ and $\mathrm{N}_{2} \mathrm{O}$ emissions, and $\mathrm{Y}$ is the grain yield. Figure 3 summarizes the methodological phases of the current work.

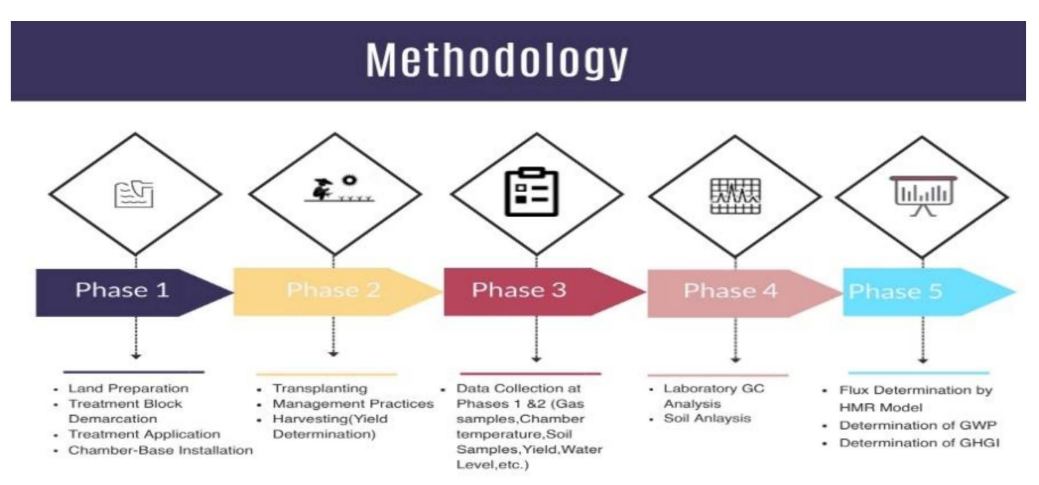

Figure 3. Depiction of methodology in phases.

\section{Results}

\subsection{Average Daily Methane $\left(\mathrm{CH}_{4}\right)$ and Nitrous Oxide $\left(\mathrm{N}_{2} \mathrm{O}\right)$ Emissions}

The highest daily average for nitrous oxide emissions was observed in BAU + $\mathrm{BIO}+\mathrm{M}$ (Table 2) and was significantly different from all treatments. Mean $\mathrm{N}_{2} \mathrm{O}$ daily emission levels for $\mathrm{T} 1$ and BAU +

\begin{tabular}{|c|c|c|c|c|c|}
\hline Treatment & Soil Amendment & $\begin{array}{c}\mathrm{N}_{2} \mathrm{O} \\
\left(\mathrm{kgNha}^{-1} \text { day }^{-1}\right)\end{array}$ & SD & $\begin{array}{c}\mathrm{CH}_{4} \\
\left(\mathrm{kgCH}_{4} \mathrm{ha}^{-1} \mathrm{day}^{-1}\right)\end{array}$ & SD \\
\hline BAU & NPK $\left(300 \mathrm{kgha}^{-1}+50 \mathrm{kgha}^{-1}\right.$ Urea $\left.(46 \% \mathrm{~N})\right)$ & $0.22 \mathrm{ab}$ & \pm 0.09 & $1.10^{\mathrm{a}}$ & \pm 1.53 \\
\hline $\mathrm{BAU}+\mathrm{BIO}$ & BAU +28 tha $^{-1}$ Biochar & $0.20^{b}$ & \pm 0.12 & $4.76^{\mathrm{a}}$ & \pm 4.87 \\
\hline $\mathrm{BAU}+\mathrm{M}$ & Manure $\left(3\right.$ tha $\left.^{-1}\right)+$ BAU & $0.27^{\mathrm{ab}}$ & \pm 0.08 & $1.20^{\mathrm{a}}$ & \pm 1.77 \\
\hline $\begin{array}{c}\mathrm{BAU}+\mathrm{BIO} \\
+\mathrm{M}\end{array}$ & BAU + Biochar + Manure & $0.38^{a}$ & \pm 0.18 & $1.57^{\mathrm{a}}$ & \pm 2.20 \\
\hline CONTROL & No amendment & $0.02^{c}$ & \pm 0.03 & $2.71^{\mathrm{a}}$ & \pm 2.77 \\
\hline
\end{tabular}
$\mathrm{M}$ were not significantly different. The control treatment recorded the lowest $\mathrm{N}_{2} \mathrm{O}$ emission levels.

Table 2. Daily mean emissions.

$\mathrm{a}, \mathrm{b}$ : Values in the same row within same parameters followed by different letters are significantly different at $p>0.05$ according to Fishers Least Significant Difference (LSD) post-hoc test for the separation of means. 


\subsection{Seasonal Cumulative Methane $\left(\mathrm{CH}_{4}\right)$ and Nitrous Oxide $\left(\mathrm{N}_{2} \mathrm{O}\right)$ Emissions}

Seasonal $\mathrm{N}_{2} \mathrm{O}$ emissions ranged from 1.61 to $58.08 \mathrm{kgN}_{2} \mathrm{Oha}^{-1}$ Season $^{-1}$. BAU $+\mathrm{BIO}+\mathrm{M}$ had the highest seasonal cumulative flux and was significantly different from all other treatments. Except the control treatment, $\mathrm{BAU}+\mathrm{BIO}$ recorded the lowest seasonal flux mean for $\mathrm{N}_{2} \mathrm{O}$ (Table 3).

Table 3. Mean seasonal cumulative emissions $\left(\mathrm{kgha}^{-1}\right.$ Season $\left.^{-1}\right)$.

\begin{tabular}{ccccc}
\hline Treatment & $\mathbf{N}_{\mathbf{2}} \mathbf{O}$ & $\mathbf{S D}$ & $\mathbf{C H}_{\mathbf{4}}$ & SD \\
\hline BAU & $39.93^{\mathrm{b}}$ & \pm 15.76 & $153^{\mathrm{a}}$ & \pm 206.35 \\
BAU + BIO & $26.84^{\mathrm{bc}}$ & \pm 29.04 & $626.83^{\mathrm{a}}$ & \pm 589.35 \\
BAU + M & $44.75^{\mathrm{b}}$ & \pm 10.28 & $169.18^{\mathrm{a}}$ & \pm 241.72 \\
BAU + BIO + M & $58.08^{\mathrm{a}}$ & \pm 19.69 & $230.94^{\mathrm{a}}$ & \pm 302.75 \\
CONTROL & $1.61^{\mathrm{c}}$ & \pm 1.63 & $389.53^{\mathrm{a}}$ & \pm 284.24 \\
\hline
\end{tabular}

$a, b, c$ : Values in the same row within same parameters followed by different letters are significantly different at $p>0.05$ according to Fishers LSD post-hoc test for the separation of means.

Early flux levels were observed in all treatments except the control approximately 13 days after the incorporation of manure and Biochar into the relevant plots. This represented the first peak for $\mathrm{N}_{2} \mathrm{O}$ emissions during the season. Generally, a more consistent rise in $\mathrm{N}_{2} \mathrm{O}$ emissions occurred between 8 DAT and 37 DAT peaking at 23 DAT, a day after the application of the first split of Nitrogen Fertilizer. The period between 8 DAT and 37 DAT also corresponded with the period of vigorous vegetative growth of the rice plants vis fresh root initiation, and minimum and maximum tillering (Figure 4).

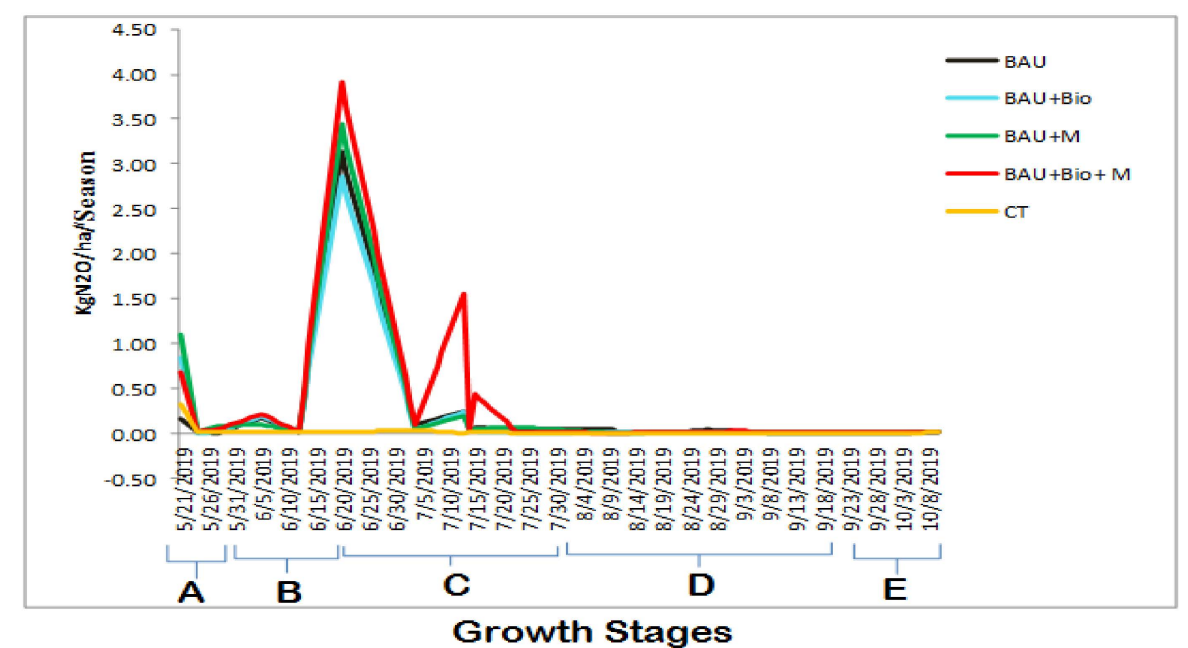

Figure 4. Seasonal cumulative nitrous oxide emissions. Key: A = Fallow Stage B = Vegetative Stage C $=$ Reproductive Stage $\mathrm{C}=$ Ripening Stage $\mathrm{E}=$ After Harvest.

The seasonal cumulative methane emissions ranged between 153 and $626.83 \mathrm{kgCH}_{4} \mathrm{ha}^{-1}$ Season $^{-1}$ across treatments. Among treatments, seasonal $\mathrm{CH}_{4}$ flux means were not significantly different. However, treatment $2(\mathrm{BAU}+\mathrm{BIO})$ recorded the highest seasonal mean. The control treatment recorded the second highest flux mean. Treatments 4 and 3 recorded the third and fourth highest seasonal flux means, respectively. The conventional farmer practice (BAU) recorded the lowest methane seasonal flux at $153 \mathrm{kgha}^{-1}$ season $^{-1}$.

A total of 2 weeks (13 DAT) after the incorporation of Biochar and poultry manure into relevant plots, all treatments recorded negative methane fluxes except the control treatment.

Early but low peaks for methane flux across all treatments occurred between 3 DAT and 37 DAT (Figure 5). Between these periods, two rain days were recorded and fertilizer was applied to 22 DAT. The highest growing season methane peaks for all treatments occurred during the period when the rice 
plants neared maturity from the spikelet initiation stage to harvesting (37 DAT-100 DAT). This period also corresponded with the longest waterlogged period during the season.

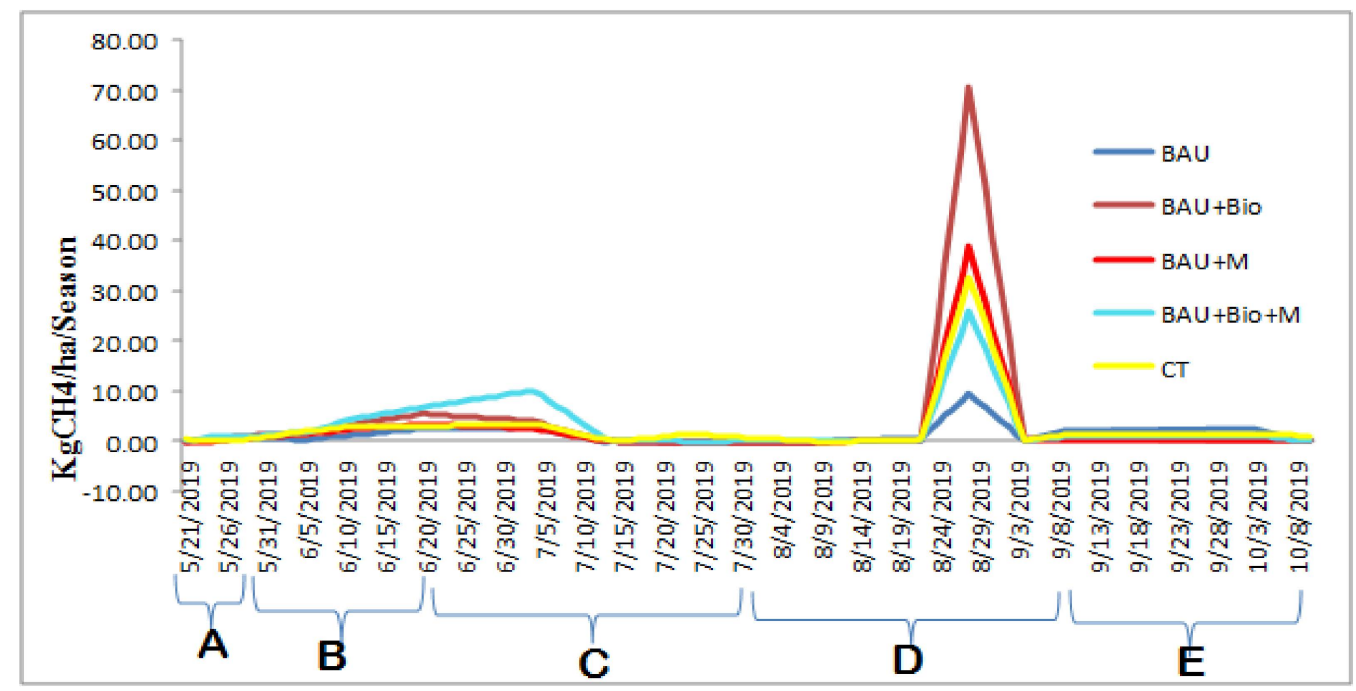

Growth Stages

Figure 5. Seasonal cumulative methane emissions.

\subsection{Global Warming Potential, Yield and Greenhouse Gas Intensity}

Estimated net GWP based on seasonal cumulative GHG emissions among treatments ranged from 5099.16 to $20,894.58$ and 756.28 to $27,201.54 \mathrm{kgCO}_{2}$ eqha $^{-1}$ Season $^{-1}$ for $\mathrm{CH}_{4}$ and $\mathrm{N}_{2} \mathrm{O}$, respectively (Table 4). The contribution of $\mathrm{N}_{2} \mathrm{O}$ emissions to net GWP was higher, between 70 to $80 \%$, than $\mathrm{CH}_{4}$ in all treatments except BAU $+\mathrm{BIO}$ and control treatment (CT) which contributed dominant methane GWP of $68 \%$ and $96 \%$, respectively.

Table 4. Seasonal Global Warming Potential (GWP), yield, and Gross Greenhouse Gas Intensity (GHGI).

\begin{tabular}{|c|c|c|c|c|c|c|c|c|c|c|}
\hline \multirow[b]{2}{*}{ Treatment } & \multicolumn{4}{|c|}{ Net Seasonal GWP $\left(\mathrm{kgCO}_{2}\right.$ eqha $^{-1}$ Season $\left.^{-1}\right)$} & \multicolumn{2}{|c|}{$\begin{array}{c}\text { Gross Seasonal GWP } \\
\left(\mathrm{kgCO}_{2} \text { eqha }^{-1} \text { Season }^{-1}\right)\end{array}$} & \multicolumn{2}{|c|}{ Yield $\left(\mathrm{Kgha}^{-1}\right)$} & \multicolumn{2}{|c|}{$\begin{array}{c}\text { Gross Greenhouse } \\
\text { Gas Intensity } \\
\text { (GGHGI) } \\
\mathrm{kgCO}_{2} \mathrm{eq} \mathrm{kg}^{-1}\end{array}$} \\
\hline & $\mathrm{N}_{2} \mathrm{O}$ & SD & $\mathrm{CH}_{4}$ & SD & GGWP & SD & YIELD & SD & GGHGI & SD \\
\hline BAU & $18,698.64^{\mathrm{ab}}$ & \pm 7383.78 & $5099.16^{\mathrm{a}}$ & \pm 6878.43 & $23,797.82^{a}$ & \pm 7411.43 & $5290.83^{\mathrm{b}}$ & \pm 222.36 & $4.49^{b}$ & \pm 1.40 \\
\hline $\begin{array}{c}\text { BAU + } \\
\text { BIO }\end{array}$ & $12,571.13 \mathrm{bc}$ & \pm 13602.96 & $20,894.58^{\mathrm{a}}$ & $\pm 19,645.04$ & $33,465.63^{\mathrm{a}}$ & $\pm 21,002.97$ & $5318.33^{b}$ & \pm 148.49 & $8.19^{\mathrm{a}}$ & \pm 1.25 \\
\hline $\mathrm{BAU}+\mathrm{M}$ & $20,959.88^{a b}$ & \pm 4814.37 & $5639.33^{\mathrm{a}}$ & \pm 8057.59 & $26,599.22^{\text {a }}$ & $\pm 11,562.23$ & $6070.00^{\mathrm{a}}$ & \pm 323.19 & $4.38^{\mathrm{b}}$ & \pm 1.90 \\
\hline $\begin{array}{c}\mathrm{BAU}+ \\
\mathrm{BIO}+\mathrm{M}\end{array}$ & $27,201.54^{\text {a }}$ & \pm 9223.51 & $7698.25^{\text {a }}$ & $\pm 10,091.92$ & $34,899.80^{\text {a }}$ & $\pm 18,620.33$ & $5935.83^{\mathrm{a}}$ & \pm 332.68 & $6.35^{\mathrm{ab}}$ & \pm 0.94 \\
\hline CONTROL & $756.28^{c}$ & \pm 763.44 & $12,984.58^{\mathrm{a}}$ & \pm 9474.70 & $13,740.86^{\mathrm{a}}$ & \pm 9609.36 & $4395.00^{c}$ & \pm 301.28 & $3.13^{b}$ & \pm 2.19 \\
\hline
\end{tabular}

Treatments $\mathrm{BAU}+\mathrm{M}$ and $\mathrm{BAU}+\mathrm{BIO}+\mathrm{M}$ had the highest yield and were not significantly different from each other but significantly different from treatments $\mathrm{BAU}, \mathrm{BAU}+\mathrm{BIO}$, and $\mathrm{BAU}+\mathrm{M}$. Treatments BAU and BAU + BIO recorded the second highest yields which were not significantly different from each other. The yields from BAU and BAU + BIO were similar to yield levels reported by farmers in the study area $\left(5.0\right.$ tha $^{-1}$ season $\left.^{-1}\right)$. BAU $+\mathrm{M}$ and BAU $+\mathrm{BIO}+\mathrm{M}$ had yields higher than the mean yields of the experimental area. The control treatment recorded the lowest yield among all treatments. 


\section{Discussion}

There were relatively no $\mathrm{CH}_{4}$ emissions at the beginning of the season among all the treatments and this trend continued up till the third day after seedlings were transplanted. An increase in the $\mathrm{CH}_{4}$ emission rates across treatments was observed from 8 DAT when there was the initiation of fresh roots with the emissions peaking (1st peak) around the tillering stage of the rice plants at around 30 DAT. The reason for this peak may primarily be as a result of the development of anoxic soil conditions and the growth of rice plants. For methane to be produced methanogenesis must occur under strictly anaerobic conditions and this stage (8 DAT-30 DAT) of the season provided the ideal conditions. After the production of methane, its emission was likely to have been facilitated by the early growth of the rice plants. Two key pathways exist for the emission of $\mathrm{CH}_{4}$ from paddy fields [32]. The pathways are through the aerenchyma tissue of the rice plants or through ebullition of methane laden gas bubbles when the soil is disturbed physically when field is inundated or by soil internal dynamics [33-36]. The rice growth factor in the first observed methane peak was key as plant mediated gas transport constitutes over $90 \%$ of emissions as root development and vegetative growth commences [37-40].

The reasons above is further buttressed when during the near maturity stages of the rice plants between 80 to $99 \mathrm{DAT}$, the second and highest methane peak was observed for all treatments. This period corresponded with high water levels across all treatment plots and also the most developed period of the rice plants with 14 days remaining to final drainage before harvesting. Furthermore, the observed second peak is attributable to the significant availability of litter and root exudates during this advanced vegetative stage of the rice plants. The availability of litter and root exudates provides additional carbon sources which increases the availability of substrates for methanogens for methane production and emission [41]. At this late stage of the rice plants, the efficiency of emissions through the plants is also enhanced because of a well-developed aerenchyma system, the key physiological factor in rice plants that emits methane.

The microbial processes of nitrification and denitrification in the soil produce $\mathrm{N}_{2} \mathrm{O}$. The process of nitrification is anaerobic while denitrification is anaerobic, however, they are all dependent on the availability of carbon sources and the addition of organic and/or inorganic soil amendments increases the carbon source and enhances microbial activity leading to the production and emission of $\mathrm{N}_{2} \mathrm{O}[42,43]$.

The first peak for $\mathrm{N}_{2} \mathrm{O}$ emissions was observed 17 days after the incorporation of poultry manure and Biochar into relevant treatment plots. There was an immediate significance in the differences observed in nitrous oxide emissions among the treatments that had poultry manure incorporated and those without it. The reason for the observed differences in the first $\mathrm{N}_{2} \mathrm{O}$ peak was the availability of mineral $\mathrm{N}$ to soil microbes in the treatment plots as a result of the application of poultry manure. $\mathrm{N}_{2} \mathrm{O}$ emission from soil has frequently been reported after $\mathrm{N}$ fertilization [31,44,45].

The second and highest peaks for $\mathrm{N}_{2} \mathrm{O}$ emissions across all treatments coincided with the periods of first and second split fertilizer application and panicle development, during which there is vigorous vegetative growth of the rice plants. In addition to the attribution of high emissions to high availability of mineral $\mathrm{N}$ for enhanced microbial activity, the vegetative period also contributes carbon through root exudates which nourishes the microbes responsible for nitrification/denitrification. Increased $\mathrm{N}$ mineralization during the maturity stages of the rice plants has also been strongly cited as a key factor for the observation of high $\mathrm{N}_{2} \mathrm{O}$ peaks [46-48]. The reported flux levels for both $\mathrm{N}_{2} \mathrm{O}$ and $\mathrm{CH}_{4}$ in this current study is among the maiden efforts to quantify emissions from smallholder rice paddy farms in Ghana and as such there is paucity in works to locally compare results. However, the flux rates quantified are within reported ranges from works from other geographical areas with similar environmental and climate conditions.

The current study reported cumulative seasonal methane emissions of between 153 to $626 \mathrm{kgha}^{-1}$ which is similar to works in Vietnam by [3], who reported seasonal methane emissions of between 148 to $627 \mathrm{kgha}^{-1}$. In India, Khosa et al. [1] reported seasonal averages of 113-290 $\mathrm{kgha}^{-1}$.Wassmann et al. [21] have also reported seasonal fluxes for methane up to $600 \mathrm{kgCH}_{4} \mathrm{ha}^{-1}$ Season ${ }^{-1}$ from tropical and 
subtropical Asian paddy systems. In Zimbabwe, Nyamadzawo et al., [49] reported seasonal averages for $\mathrm{N}_{2} \mathrm{O}$ emissions among treatments at $0.28 \mathrm{kgha}^{-1}$ and this is similar to the treatment average of $0.27 \mathrm{kgha}^{-1}$ reported in this current study. In China where high nitrogen fertilizer rates are used, Liu et al. [50] reported higher seasonal averages for $\mathrm{N}_{2} \mathrm{O}$ emissions at $0.45 \mathrm{kgha}^{-1}$. Kim et al. [51], in their synthesis of available data on greenhouse gas emissions in natural agricultural croplands including paddy fields in Sub-Saharan Africa, saw $\mathrm{N}_{2} \mathrm{O}$ emissions ranging between 0.05 to $112.0 \mathrm{kgha}^{-1}$ season $^{-1}$.

Nitrous oxide is produced through the microbial processes of aerobic nitrification and anaerobic denitrification. These processes are enhanced when nitrogen fertilizer and/or organic matter is amended into soils as it provides a $C$ source for the microbial processes [41]. Under the current study, T2, which was an integrated treatment of (NPK $300 \mathrm{kgha}^{-1}+$ Urea $(46 \% \mathrm{~N})$ at $50 \mathrm{kgha}^{-1}$ ) and Biochar $\left(28\right.$ tha $\left.^{-1}\right)$ recorded the lowest $\mathrm{N}_{2} \mathrm{O}$ flux compared to the treatments with only inorganic fertilizer amendments and those with poultry manure. This finding is consistent with the works of Shen et al. [52] and Cayuela et al. [53] who have reported that the addition of Biochar reduced $\mathrm{N}_{2} \mathrm{O}$ emissions in paddy fields. Various explanations have been proffered as reasons why Biochar reduces $\mathrm{N}_{2} \mathrm{O}$ emissions. Kindaichi et al., [54] and Das et al., [29] reported that the ability of Biochar to increase the $\mathrm{C}: \mathrm{N}$ ratio in soils allows for heterotrophic bacteria which are subject to $\mathrm{N}$ limitation to compete with nitrifiers for available nitrogen. Typically, heterotrophic bacteria grow faster and are more abundant in soils than nitrifying bacteria. This gives the heterotrophic bacteria advantage over nitrifiers in utilization of available nitrogen, consequently reducing $\mathrm{N}_{2} \mathrm{O}$ production due to decreased nitrification rates. Low $\mathrm{N}_{2} \mathrm{O}$ emissions from Biochar-amended soils might also be due to the absorption of NH4+ by Biochar with a consequent decrease in soil $\mathrm{NH} 4+$ availability, which may limit both nitrification and denitrification [24,55]. The negative effect of Biochar on $\mathrm{N}_{2} \mathrm{O}$ emissions has also been reported to be as a result of its action on soil physical properties by improving soil porosity, enhancing aeration and also adsorbing excess soil moisture [56,57]. Biochar amended to soils have also been found to have a significant initial noxious effect on soil microbial communities $[58,59]$ due to its potential carrying of toxic organic compounds (polycyclic aromatic hydrocarbons (PAHs), polychlorinated dibenzodioxins and furans, which develops during the pyrolysis process of biomass $[60,61]$. The mechanism of these inherent toxic compounds is highly likely to alter microbial processes including nitrification and denitrification [62-64]. The release of these toxic compounds after Biochar is amended into soils has been posited as a mechanism that leads to low $\mathrm{N}_{2} \mathrm{O}$ emissions in Biochar amended soils $[60,65,66]$. The integrated treatments, $\mathrm{BAU}+\mathrm{M}$ and $\mathrm{BAU}+\mathrm{BIO}+\mathrm{M}$ that had poultry manure (PM) as constituents, recorded the highest and second highest mean flux rates, respectively (Table 3). This is explained by the low $\mathrm{C}: \mathrm{N}$ ratio typical of Poultry manure unlike Biochar. The incorporation of PM therefore promotes the rapid release of $\mathrm{N}$ needed for the microbial processes of nitrification and denitrification for high $\mathrm{N}_{2} \mathrm{O}$ emissions. The addition of organic manure also creates the ideal conditions for denitrifying bacteria to thrive as decomposing organic matter increases available labile $\mathrm{C}$ for denitrification to occur thereby increasing $\mathrm{N}_{2} \mathrm{O}$ emissions [10]. These reasons could explain why the treatments with PM had higher $\mathrm{N}_{2}$ Oflux means than the other treatments without PM.

Research on the effect of Biochar on methane emissions in rice paddies has been varied with no definite conclusions on its $\mathrm{CH}_{4}$ emission reduction abilities [13,67]. Some research works have reported reductions in soil $\mathrm{CH}_{4}$ emissions as a result of Biochar amendment [68-71], others have also reported an increase in emissions [63,72]. There has also been reports that indicated no significant effects on $\mathrm{CH}_{4}$ emissions from Biochar-amended soils [73]. In this current study, there were no significant differences in $\mathrm{CH}_{4}$ emissions among treatments (Table 3). However, treatment 2 recorded the highest seasonal mean for methane emissions (Table 3). This may be explained by a number of factors including the $\mathrm{pH}$ dynamics in the soil after Biochar was incorporated.

High $\mathrm{pH}$, which is typical of Biochar, produces a liming effect on soils into which it is incorporated $[74,75]$. Methanogens, the microbes that produce methane thrive optimally at $\mathrm{pH}$ levels between 6 to 8 , whilst methanotrophs that consume methane thrive well in more acidic 
soils [76], thus, the methane mitigating effect of Biochar is more pronounced in acidic soils where methanotrophy is enhanced. In the current study, it was observed that pre-experiment average soil $\mathrm{pH}$ of 5.44 increased to an average of 6.78 at the end of the 123-day growing in all treatment plots, seen in Appendix A Table A1. This indicates that the change in $\mathrm{pH}$ enhanced the activities of methanogens in the soil leading to a high rate of methanogenesis and consequently methane production and emission. The Biochar treatment (BAU + BIO) had a higher $\mathrm{CH}_{4}$ mean which led to a higher GWP than all the other treatments. Further, with rice straw having been found to have a positive effect on $\mathrm{CH}_{4}$ emissions $[14,77,78]$, years of its incorporation into the soil by farmers as a conventional local practice is likely to have built up a large pool of highly labile organic matter whose coupling with the observed decrease in soil $\mathrm{pH}$ led to enhanced methanogenesis. This may account for the high methane levels observed in the control plots. The reasoning above is consistent with the work of Cui et al. [79], who reported a substantial increase in $\mathrm{CH}_{4}$ production after straw application in a paddy system.

The effect of Biochar and poultry manure amendment on rice yield was recognizable in the current study. The two treatments (BAU $+\mathrm{M}$ and $\mathrm{BAU}+\mathrm{BIO}+\mathrm{M}$ ) that had Biochar and manure as components yielded significantly higher rice grains compared to other treatments without them (Table 4). The role of Biochar in the high yield recorded, is explained by its ability to directly supply nutrients such as $\mathrm{Ca}, \mathrm{Mg}, \mathrm{K}$, and $\mathrm{P}$ whilst enhancing their uptake due to high electrical conductivity (EC) values typical of Biochar $[9,18,80,81]$. EC values are an indicator of the amount of water-soluble nutrients and as a consequence, the improved soil nutrient content in the soil coupled with high water solubility will enhance nutrient uptake and have a positive effect on plant growth and yield. The poultry manure component of treatments 3 and 4 also is also likely to have had an added positive effect on plant growth and yield. Poultry manure has been found to provide a balanced supply of both micro and macro nutrients. Pronounced microbial activity in poultry manure is also able to improve the physico-chemical properties in soils $[67,82]$.There have been numerous reports that are consistent with results of the current study regarding the positive yield effect of Biochar and poultry manure as stand-alone soil amendments or in combination with inorganic fertilizers [79,83-86]. In the current study, which was carried out in the major season (March/April-August/September) of rice production in the experimental area, the percentage contribution of $\mathrm{N}_{2} \mathrm{O}$ was higher $(70-80 \%)$ than that of $\mathrm{CH}_{4}$ emissions across all treatments except (BAU + BIO) and control. The cumulative seasonal GHG estimation showed that $\mathrm{N}_{2} \mathrm{O}$ had more peaks than $\mathrm{CH}_{4}$ emissions (Figures 3 and 4). The high $\mathrm{N}_{2} \mathrm{O}$ GWP contribution reported in this current study, is at variance with numerous reports on paddy systems where $\mathrm{CH}_{4}$ emissions the dominant GHG contributing highest to seasonal and yearly GWP $[47,87,88]$. These findings have predominantly emanated from temperate irrigated paddy systems where there is control over flooding events. These areas are also highly variable regarding climatic, environmental and management factors to what pertains in Sub-Saharan Africa. These climatic and management factors to a significant extent determine the levels of emissions that emanate from rice paddies [13,89-94]. It is therefore currently difficult to make robust comparisons with findings from the temperate regions where majority of these reports emanate from. Richards et al. [95] agrees with this difficulty, when they reported in their work that there may be poor emissions estimates in tropical developing countries when GHG calculated on temperate conditions factors are employed as a basis for comparing and/or estimating tropical African emissions.

In India, Kritee et al. [96] reported high nitrous oxide emissions in intermittently flooded rice fields and posited that previous estimates may have underestimated earlier estimates by between 30 to 45 times. The reported $\mathrm{N}_{2} \mathrm{O}$ emissions in their study in the Indian sub-continent ranged between 0 to $33 \mathrm{kgha}^{-1}$. The highest $\mathrm{N}_{2} \mathrm{O}$ flux from their work was recorded from fields that underwent multiple aeration periods. The field condition under this current study is similar to the Indian experimental condition and with inorganic fertilizer application rate of $350 \mathrm{kgha}^{-1}$ plus poultry manure amendments, it is not unusual to have recorded high $\mathrm{N}_{2} \mathrm{O}$ emissions in the current study. The authors further concluded that rainfed farms are at risk for elevated rice- $\mathrm{N}_{2} \mathrm{O}$ emissions. In a 
study by Nyamadzawo et al. [49] the authors recorded low seasonal $\mathrm{CH}_{4}$ emissions in Zimbabwe and indicated that rain-fed paddy systems may be a weak source for $\mathrm{CH}_{4}$ emissions.

It is established that the water regime in a paddy system is the most important factor that controls the $\mathrm{CH}_{4}$ and $\mathrm{N}_{2} \mathrm{O}$ emission levels [2,97-100]. With high dependence on rain coupled with weak to nonexistent irrigation infrastructure in Ghana's paddy rice systems to manage water, low rainfall levels coupled with high temperatures mean that fields quickly dry out reducing the anoxic soil conditions required for methanogenesis. For the period of this experiment, two rain days were recorded with an average above soil water level of $0.8 \mathrm{~cm}$ across treatment plots enhancing the aerobic field conditions necessary for the microbial processes of nitrification and denitrification. The amendment of the soil with poultry manure together with the inorganic fertilizers may also have accounted for the high $\mathrm{N}_{2} \mathrm{O}$ emissions which led to higher seasonal $\mathrm{N}_{2} \mathrm{O}$ GWP. In the current study, the treatments that had poultry manure and/or inorganic fertilizer as component soil amendment had significantly higher seasonal emissions levels (Table 3). Akiyama and Tsuruta [8] reported high $\mathrm{N}_{2} \mathrm{O}$ emissions associated with poultry manure when they investigated the effect of poultry and swine manure on Nitrous oxide, $\mathrm{NO}$, and $\mathrm{N}_{2} \mathrm{O}$ fluxes.

The effect of Biochar and poultry manure amendment on rice yield was recognizable in the current study. The two treatments $(\mathrm{BAU}+\mathrm{M}$ and $\mathrm{BAU}+\mathrm{BIO}+\mathrm{M})$ that had Biochar and manure as components yielded significantly higher rice grains compared to other treatments without them (Table 3). The role of Biochar in the high yield recorded, is explained by its ability to directly supply nutrients such as $\mathrm{Ca}, \mathrm{Mg}, \mathrm{K}$, and $\mathrm{P}$ whilst enhancing their uptake due to high electrical conductivity values typical of Biochar $[9,80,83,86,101]$. EC values are an indicator of the amount of water-soluble nutrients [82]. As a consequence, the improved soil nutrient content in the soil coupled with high water solubility will enhance nutrient uptake and have a positive effect on plant growth and yield. The poultry manure component of treatments 3 and 4 is also likely to have had an added positive effect on plant growth and yield. Poultry manure has been found to provide a balanced supply of both micro and macro nutrients. Pronounced microbial activity in poultry manure is also able to improve the physico-chemical properties in soils $[47,88,102]$. There have been numerous reports that are consistent with results of the current study regarding the positive yield effect of Biochar and poultry manure as stand-alone soil amendments or in combination with inorganic fertilizers $[89,90]$.

The peculiar nature of most rainfed paddy system in SSA where there is very little control on water management may predispose smallholder paddy production to high $\mathrm{N}_{2} \mathrm{O}$ emissions. In this study, the contribution of $\mathrm{N}_{2} \mathrm{O}$ emissions to GWP shows that smallholder production systems are likely to be a key source of higher than currently anticipated $\mathrm{N}_{2} \mathrm{O}$ emissions. The integrative amendment of soil with organic materials, poultry manure, and Biochar enhanced crop performance and delivered low greenhouse gas intensity in one scenario in the current study.

\section{Conclusions}

The utilization of organic soil amendments viz Biochar and poultry manure as components of the conventional inorganic means of soil amendments proved to have a positive effect on rice yield. The integrated approach of combining organic and inorganic fertilizers used in this study was effective in delivering higher yields than the conventional practice of farmers alone, particularly, poultry manure use as a component soil amendment. This gives a strong indication of the feasibility of organic fertilizer as a sustainable means of augmenting inorganic soil amendments for increased rice yield. Biochar produced from straw as was the case in this study provides a sustainable means of managing waste after harvest and reduces the tendency of farmers to burn harvest residue which pollutes the environment.

The determination of a sustainable production system in terms of emissions is the ability of that system to produce less emission per kilogram of yield. Higher yields offset the emissions associated with a production system. The objective of this work was to determine a soil fertilization option that could produce high yields with low emissions (eco-friendly yield). The fertilization option of poultry 
manure and conventional inorganic fertilizer $(B A U+M)$ recorded the lowest emission per kilogram of yield. This work concludes that the continuous use of poultry manure in combination with the BAU practice of farmers will likely lead to improvements in yield and lead to reductions in the emissions per kilogram of yield (eco-friendly yields).

This work was limited by the unavailability of funding support to conduct a multiple season study to determine the long-term effects of the studied treatments. It is therefore recommended that a multiseasonal study is conducted to determine the long-term effects of especially the (BAU $+M)$ fertilization type on smallholder rice yield and emissions to determine its suitability for scaling.

Author Contributions: Conceptualization, K.K.B., G.Y.O. and E.M.; design of the study, K.K.B., G.Y.O. and E.M.; literature review, K.K.B., G.Y.O. and E.M.; field data gathering and laboratory generated data analysis, K.K.B.; scientific content and structure, K.K.B., G.Y.O. and E.M.; initial draft review, G.Y.O. and E.M.; second draft review and content fine-tuning-K.K.B., G.Y.O. and E.M. All authors have read and agreed to the published version of the manuscript.

Funding: This research received no external funding.

Acknowledgments: We would like to acknowledge the Consultative Group On International Agricultural Research program on climate change and food security (CGIAR-CCAFS), Global Research Alliance program on Greenhouse gas emissions (GRA_GHG) for their generous award of a 6-month training fellowship with the United States Department Of Agriculture-Agricultural Research Service, Pendleton-Oregon, where K.K.B. received valuable technical training on emissions research and data analysis that has contributed significantly to the study and write-up of this paper.

Conflicts of Interest: The authors declare no conflict of interest. 


\section{Appendix A}

Table A1. Soil parameters.

\begin{tabular}{|c|c|c|c|c|c|c|c|c|c|c|c|c|c|c|c|c|}
\hline Labels & pH 1:2.5 & $\%$ & $\%$ Total & $\%$ Organic & $\begin{array}{c}\text { Exchangeable } \\
\text { Cations cmol/kg }\end{array}$ & & & & $\mathrm{cmol} / \mathrm{kg}$ & $\mathrm{cmol} / \mathrm{kg}$ & $\mathrm{cmol} / \mathrm{kg}$ & $\%$ & AVi.BRAYS & $\begin{array}{c}\text { Mechanical } \\
\text { Analysis }\end{array}$ & & \\
\hline & & O.C & NITROGEN & MATTER & $\mathrm{Ca}$ & $\mathrm{Mg}$ & $\mathrm{K}$ & $\mathrm{Na}$ & T.E.B & $\begin{array}{c}\text { EX. } \\
\text { ACIDITY }\end{array}$ & ECEC & $\begin{array}{l}\text { Base } \\
\text { Sat. }\end{array}$ & ppmP & $\%$ Sand & $\%$ Silt & $\%$ Clay \\
\hline $\begin{array}{l}\text { Soil Parameters } \\
\text { Before Study }\end{array}$ & 5.442 & 1.37 & 0.12 & 2.36 & 2.96 & 1.32 & 0.99 & 0.05 & 5.32 & 0.74 & 6.05 & 86.84 & 1.40 & 48.00 & 32.40 & 19.60 \\
\hline \multicolumn{17}{|l|}{ After Harvesting } \\
\hline BAU(T1) & 6.84 & 0.88 & 0.0532 & 1.51 & 8 & 1.4 & 0.495 & 0.0782 & & & & & & 46.96 & 31.28 & 21.76 \\
\hline BAU+Bio(T2) & 6.8 & 0.88 & 0.0504 & 1.51 & 7 & 3.4 & 2.027 & 0.15 & & & & & & 58.38 & 19.50 & 22.12 \\
\hline BAU+M(T3) & 6.72 & 0.84 & 0.0504 & 1.44 & 5.6 & 3.2 & 0.561 & 0.12 & & & & & & 49.32 & 28.92 & 21.76 \\
\hline $\mathrm{BAU}+\mathrm{M}+\mathrm{Bio}(\mathrm{T} 4)$ & 6.77 & 1.08 & 0.049 & 1.86 & 7.4 & 1.2 & 2.093 & 0.15 & & & & & & 50.96 & 27.64 & 21.40 \\
\hline Control(T5) & 6.77 & 0.6 & 0.0532 & 1.03 & 5.4 & 2.6 & 0.561 & 0.15 & & & & & & 76.40 & 9.28 & 14.32 \\
\hline
\end{tabular}




\section{References}

1. Khosa, M.K.; Sidhu, B.S.; Benbi, D.K. Effect of organic materials and rice cultivars on methane emission from rice field. J. Environ. Biol. 2010, 31, 281-285. [PubMed]

2. Sander, B.O.; Samson, M.; Buresh, R.J. Methane and nitrous oxide emissions from flooded rice fields as affected by water and straw management between rice crops. Geoderma 2014, 235, 355-362. [CrossRef]

3. Tariq, A.; Vu, Q.D.; Jensen, L.S.; de Tourdonnet, S.; Sander, B.O.; Wassmann, R.; van Mai, T.; de Neergaard, A. Mitigating $\mathrm{CH}_{4}$ and $\mathrm{N}_{2} \mathrm{O}$ emissions from intensive rice production systems in northern Vietnam: Efficiency of drainage patterns in combination with rice residue incorporation. Agric. Ecosyst. Environ. 2017, 249, 101-111. [CrossRef]

4. Hogarth, J.R.; Haywood, C.; Whitley, S. Low-Carbon Development in Sub-Saharan Africa: 20 Cross-Sector Transitions; Overseas Development Institute: London, UK, 2015.

5. Intergovernmental Panel on Climate Change. Agriculture, Forestry and Other Land Use (AFOLU). In Climate Change 2014: Mitigation of Climate Change; IPCC Working Group III Contribution to AR5; Cambridge University Press: Cambridge, UK, 2015; pp. 811-922. [CrossRef]

6. Smith, P.; Bustamante, M.; Ahammad, H.; Clark, H.; Dong, H.; Elsiddig, E.A.; Haberl, H.; Harper, R.; House, J.; Jafari, M.; et al. Agriculture, Forestry and Other Land Use (AFOLU). In Climate Change. Mitigation of Climate Change; Contribution of Working Group III to the Fifth Assessment Report of the Intergovernmental Panel on Climate Change; Edenhofer, O., Pichs-Madruga, R., Sokona, Y., Farahani, E., Kadner, S., Seyboth, K., Adler, A., Baum, I., Brunner, S., Eickemeier, P., et al., Eds.; Cambridge University Press: Cambridge, UK; New York, NY, USA, 2014.

7. Chen, X.; Cui, Z.; Fan, M.; Vitousek, P.; Zhao, M.; Ma, W.; Wang, Z. Producing more grain with lower environmental costs. Nature 2014, 514, 486-489. [CrossRef] [PubMed]

8. Akiyama, H.; Tsuruta, H. Nitrous oxide, nitric oxide, and nitrogen dioxide fluxes from soils after manure and urea application. J. Environ. Qual. 2003, 32, 423-431. [CrossRef] [PubMed]

9. Dong, D.; Feng, Q.; Mcgrouther, K.; Yang, M.; Wang, H.; Wu, W. Effects of biochar amendment on rice growth and nitrogen retention in a waterlogged paddy field. J. Soils Sediments 2015, 15, 153-162. [CrossRef]

10. Novais, S.V.; Zenero, M.D.O.; Junior, E.F.F.; de Lima, R.P.; Cerri, C.E.P. Mitigation of greenhouse gas emissions from tropical soils amended with poultry manure and sugar cane straw biochars. Agric. Sci. 2017, 8, 887-903.

11. Chen, D.; Wang, C.; Shen, J.; Li, Y.; Wu, J. Response of $\mathrm{CH}_{4}$ emissions to straw and biochar applications in double-rice cropping systems: Insights from observations and modeling. Environ. Pollut. 2018, 235, 95-103. [CrossRef]

12. Huang, M.; Fan, L.; Chen, J.; Jiang, L.; Zou, Y. Continuous applications of biochar to rice: Effects on nitrogen uptake and utilization. Sci. Rep. 2018, 8, 11461. [CrossRef]

13. Trong Hung, D.; Hughes, H.J.; Keck, M.; Sauer, D. Rice-Residue Management Practices of Smallholder Farms in Vietnam and Their Effects on Nutrient Fluxes in the Soil-Plant System. Sustainability 2019, 11, 1641. [CrossRef]

14. Jiang, Z.; Lian, F.; Wang, Z.; Xing, B. The role of biochars in sustainable crop production and soil resiliency. J. Exp. Bot. 2020, 71, 520-542. [CrossRef] [PubMed]

15. Sander, B.O.; Quilty, J.; Balingbing, C.; Castalone, A.G.; Romasanta, R.; Alberto, M.C.R.; Sandro, J.M.; Jamieson, C.; Gummert, M. An assessment of irrigated rice production energy efficiency and environmental footprint with in-field and off-field rice straw management practices. Sci. Rep. 2019, 9, 16887.

16. Duy Pham, D.; Cai, K.; Phung, L.D.; Kaku, N.; Sasaki, A.; Sasaki, Y.; Horiguchi, K.; Pham, D.V.; Watanabe, T. Rice cultivation without synthetic fertilizers and performance of Microbial Fuel Cells (MFCs) under continuous irrigation with treated wastewater. Water 2019, 11, 1516. [CrossRef]

17. Arunrat, N.; Pumijumnong, N. Practices for reducing greenhouse gas emissions from rice production in Northeast Thailand. Agriculture 2017, 7, 4. [CrossRef]

18. Hussain, S.; Peng, S.; Fahad, S.; Khaliq, A.; Huang, J.; Cui, K.; Nie, L. Rice management interventions to mitigate greenhouse gas emissions: A review. Environ. Sci. Pollut. Res. 2015, 22, 3342-3360. [CrossRef] 
19. Wang, C.; Liu, J.; Shen, J.; Chen, D.; Li, Y.; Jiang, B.; Wu, J. Effects of biochar amendment on net greenhouse gas emissions and soil fertility in a double rice cropping system: A 4-year field experiment. Agric. Ecosyst. Environ. 2018, 262, 83-96. [CrossRef]

20. Aulakh, M.S.; Wassmann, R.; Bueno, C.; Kreuzwieser, J.; Rennenberg, H. Characterization of root exudates at different growth stages of ten rice (Oryza sativa L.) cultivars. Plant Biol. 2001, 3, 139-148. [CrossRef]

21. Wassmann, R.; Buendia, L.V.; Lantin, R.S.; Bueno, C.S.; Lubigan, L.A.; Umali, A.; Nocon, N.N.; Javellana, A.M.; Neue, H.U. Mechanisms of crop management impact on methane emissions from rice fields in Los Baños, Philippines. Nutr. Cycl. Agroecosyst. 2000, 58, 107-119. [CrossRef]

22. Yagi, K.; Tsuruta, H.; Minami, K. Possible options for mitigating methane emission from rice cultivation. Nutr. Cycl. Agroecosyst. 1997, 49, 213-220. [CrossRef]

23. Linquist, B.A.; Adviento-Borbe, M.A.; Pittelkow, C.M.; van Kessel, C.; jan van Groenigen, K. Fertilizer management practices and greenhouse gas emissions from rice systems: A quantitative review and analysis. Field Crops Res. 2012, 135, 10-21. [CrossRef]

24. Sampanpanish, P.; Alam, L.; Mohamed, C.A.; Mokhtar, M.B.; Han, E.C.; Huang, Y.C.; Lin, J.M.; Lin, H.J.; $\mathrm{Wu}$, J.Y.; Lee, C.C.; et al. Use of organic fertilizer on paddy fields to reduce greenhouse gases. Sci. Asia 2012, 38, 323-330. [CrossRef]

25. Ghana Statistical Service. 2010 Population and Housing Census Report; Ghana Statistical Service: Ghana, West Africa, 2014.

26. Minamikawa, K.; Takeshi, T.; Shigeto, S.; Agnes, P.; Kazuyuki, Y. Guidelines for Measuring $\mathrm{CH}_{4}$ and $\mathrm{N}_{2} \mathrm{O}$ Emissions from Rice Paddies by a Manually Operated Closed Chamber Method; National Institute for Agro-Environmental Sciences: Tsukuba, Japan, 2015; p. 76.

27. Pedersen, A.R.; Petersen, S.O.; Schelde, K. A comprehensive approach to soil-atmosphere trace-gas flux estimation with static chambers. Eur. J. Soil Sci. 2010, 61, 888-902. [CrossRef]

28. Hutchinson, G.L.; Mosier, A.R. Improved soil cover method for field measurement of nitrous oxide fluxes. Soil Sci. Soc. Am. J. 1981, 45, 311-316. [CrossRef]

29. Das, S.; Ghosh, A.; Adhya, T.K. Nitrous oxide and methane emission from a flooded rice field as influenced by separate and combined application of herbicides bensulfuron methyl and pretilachlor. Chemosphere 2011, 84, 54-62. [CrossRef] [PubMed]

30. Wang, W.; Wu, X.; Chen, A.; Xie, X.; Wang, Y.; Yin, C. Mitigating effects of ex situ application of rice straw on $\mathrm{CH}_{4}$ and $\mathrm{N}_{2} \mathrm{O}$ emissions from paddy-upland coexisting system. Sci. Rep. 2016, 6, 37402. [CrossRef]

31. Das, S.; Adhya, T.K. Effect of combine application of organic manure and inorganic fertilizer on methane and nitrous oxide emissions from a tropical flooded soil planted to rice. Geoderma 2014, 213, 185-192. [CrossRef]

32. Butterbach-Bahl, K.; Papen, H.; Rennenberg, H. Impact of gas transport through rice cultivars on methane emission from rice paddy fields. Plant Cell Environ. 1997, 20, 1175-1183. [CrossRef]

33. Nouchi, I.; Mariko, S.; Aoki, K. Mechanism of methane transport from the rhizosphere to the atmosphere through rice plants. Plant Physiol. 1990, 94, 59-66. [CrossRef]

34. Wang, B.; Neue, H.U.; Samonte, H.P. Role of rice in mediating methane emission. Plant Soil 1997, 189, $107-115$. [CrossRef]

35. Schütz, H.; Seiler, W.; Conrad, R. Processes involved in formation and emission of methane in rice paddies. Biogeochemistry 1989, 7, 33-53. [CrossRef]

36. Wassmann, R.; Neue, H.U.; Alberto, M.C.R.; Lantin, R.S.; Bueno, C.; Llenaresas, D.; Arah, J.R.M.; Papen, H.; Seiler, W.; Rennenberg, H. Fluxes and pools of methane in wetland rice soils with varying organic inputs. Environ. Monit. Assess. 1996, 42, 163-173. [CrossRef] [PubMed]

37. Cicerone, R.J.; Shetter, J.D. Sources of atmospheric methane: Measurements in rice paddies and a discussion. J. Geophys. Res. Oceans 1981, 86, 7203-7209. [CrossRef]

38. Den Van der Gon, H.A.; Van Breemen, N. Diffusion-controlled transport of methane from soil to atmosphere as mediated by rice plants. Biogeochemistry 1993, 21, 177-190. [CrossRef]

39. Holzapfel-Pschorn, A.; Conrad, R.; Seiler, W. Effects of vegetation on the emission of methane from submerged paddy soil. Plant Soil 1986, 92, 223-233. [CrossRef] 
40. Gaihre, Y.K.; Tirol-Padre, A.; Wassmann, R.; Aquino, E.; Pangga, G.V.; Sta-Cruz, P.C. Spatial and temporal variations in methane fluxes from irrigated lowland rice fields. Philipp. Agric. Sci. 2011, 94, 335-342.

41. Davidson, E.A. Fluxes of nitrous oxide and nitric oxide from terrestrial ecosystems. In Microbial Production and Consumption of Greenhouse Gases: Methane, Nitrous Oxide, and Halomethanes; American Society for Microbiology: Washington, DC, USA, 1991; pp. 219-235.

42. Granli, T.; Bøckman, O.C. Nitrous oxide from agriculture. Nor. J. Agric. Sci. 1994, 12, 1-25.

43. Adviento-Borbe, M.A.; Pittelkow, C.M.; Anders, M.; van Kessel, C.; Hill, J.E.; McClung, A.M.; Six, J.; Linquist, B.A. Optimal fertilizer nitrogen rates and yield-scaled global warming potential in drill seeded rice. J. Environ. Qual. 2013, 42, 1623-1634. [CrossRef]

44. Myint, A.K.; Yamakawa, T.; Zenmyo, T.; Thao, H.T.B.; Sarr, P.S. Effects of organic-manure application on growth, grain yield, and nitrogen, phosphorus, and potassium recoveries of rice variety Manawthuka in paddy soils of differing fertility. Commun. Soil Sci. Plant Anal. 2011, 42, 457-474. [CrossRef]

45. Rahman, F.; Rahman, M.M.; Rahman, G.K.M.M.; Saleque, M.A.; Hossain, A.T.M.S.; Miah, M.G. Effect of organic and inorganic fertilizers and rice straw on carbon sequestration and soil fertility under a rice-rice cropping pattern. Carbon Manag. 2016, 7, 41-53. [CrossRef]

46. Van Groenigen, J.W.; Oenema, O.; jan van Groenigen, K.; Velthof, G.; van Kessel, C. Best nitrogen management practices to decrease greenhouse gas emissions. Better Crop. 2011, 95, 16-17.

47. Wang, C.; Lai, D.Y.F.; Sardans, J.; Wang, W.; Zeng, C.; Peñuelas, J. Factors related with $\mathrm{CH}_{4}$ and $\mathrm{N}_{2} \mathrm{O}$ emissions from a paddy field: Clues for management implications. PLoS ONE 2017, 12, e0169254. [CrossRef] [PubMed]

48. Peco, B.; Navarro, E.; Carmona, C.P.; Medina, N.G.; Marques, M.J. Effects of grazing abandonment on soil multifunctionality: The role of plant functional traits. Agric. Ecosyst. Environ. 2017, 249, 215-225. [CrossRef]

49. Nyamadzawo, G.; Wuta, M.; Chirinda, N.; Mujuru, L.; Smith, J.L. Greenhouse Gas Emissions from Intermittently Flooded (Dambo) Rice under Different Tillage Practices in Chiota Smallholder Farming Area of Zimbabwe. Atmos. Clim. Sci. 2013, 3, 13-20. [CrossRef]

50. Liu, J.; Shen, J.; Li, Y.; Su, Y.; Ge, T.; Jones, D.L.; Wu, J. Effects of biochar amendment on the net greenhouse gas emission and greenhouse gas intensity in a Chinese double rice cropping system. Eur. J. Soil Biol. 2014, 65, 30-39. [CrossRef]

51. Kim, D.-G.; Thomas, A.D.; Pelster, D.; Rosenstock, T.S.; Sanz-Cobena, A. Reviews and syntheses: Greenhouse gas emissions in natural and agricultural lands in sub-Saharan Africa: Synthesis of available data and suggestions for further studies. Biogeosci. Discuss. 2015, 12, 16479-16526. [CrossRef]

52. Shen, J.; Tang, H.; Liu, J.; Wang, C.; Li, Y.; Ge, T.; Jones, D.L.; Wu, J. Contrasting effects of straw and straw-derived biochar amendments on greenhouse gas emissions within double rice cropping systems. Agric. Ecosyst. Environ. 2014, 188, 264-274. [CrossRef]

53. Cayuela, M.L.; van Zwieten, L.; Singh, B.P.; Jeffery, S.; Roig, A.; Sánchez-Monedero, M.A. Biochar's role in mitigating soil nitrous oxide emissions: A review and meta-analysis. Agric. Ecosyst. Environ. 2014, 191, 5-16. [CrossRef]

54. Kindaichi, T.; Ito, T.; Okabe, S. Ecophysiological interaction between nitrifying bacteria and heterotrophic bacteria in autotrophic nitrifying biofilms as determined by microautoradiography-fluorescence in situ hybridization. Appl. Environ. Microbiol. 2004, 70, 1641-1650. [CrossRef]

55. Signor, D.; Cerri, C.E.P. Nitrous oxide emissions in agricultural soils: A review. Pesqui. Agropecuária Trop. 2013, 43, 322-338. [CrossRef]

56. Rogovska, N.; Laird, D.; Cruse, R.; Fleming, P.; Parkin, T.; Meek, D. Impact of biochar on manure carbon stabilization and greenhouse gas emissions. Soil Sci. Soc. Am. J. 2011, 75, 871-879. [CrossRef]

57. Yanai, Y.; Toyota, K.; Okazaki, M. Effects of charcoal addition on $\mathrm{N}_{2} \mathrm{O}$ emissions from soil resulting from rewetting air-dried soil in short-term laboratory experiments. Soil Sci. Plant Nutr. 2007, 53, 181-188. [CrossRef]

58. Gell, K.; van Groenigen, J.; Cayuela, M.L. Residues of bioenergy production chains as soil amendments: Immediate and temporal phytotoxicity. J. Hazard. Mater. 2011, 186, 2017-2025. [CrossRef] [PubMed] 
59. Dempster, D.N.; Gleeson, D.B.; Solaiman, Z.M.; Jones, D.L.; Murphy, D.V. Decreased soil microbial biomass and nitrogen mineralisation with Eucalyptus biochar addition to a coarse textured soil. Plant Soil 2012, 354, 311-324. [CrossRef]

60. Hale, S.E.; Lehmann, J.; Rutherford, D.; Zimmerman, A.R.; Bachmann, R.T.; Shitumbanuma, V.; O’Toole, A.; Sundqvist, K.L.; Arp, H.P.H.; Cornelissen, G. Quantifying the total and bioavailable polycyclic aromatic hydrocarbons and dioxins in biochars. Environ. Sci. Technol. 2012, 46, 2830-2838. [CrossRef]

61. Hilber, I.; Blum, F.; Leifeld, J.; Schmidt, H.P.; Bucheli, T.D. Quantitative determination of PAHs in biochar: A prerequisite to ensure its quality and safe application. J. Agric. Food Chem. 2012, 60, 3042-3050. [CrossRef]

62. Sverdrup, L.E.; Ekelund, F.; Krogh, P.H.; Nielsen, T.; Johnsen, K. Soil microbial toxicity of eight polycyclic aromatic compounds: Effects on nitrification, the genetic diversity of bacteria, and the total number of protozoans. Environ. Toxicol. Chem. Int. J. 2002, 21, 1644-1650. [CrossRef]

63. Maliszewska-Kordybach, B.; Klimkowicz-Pawlas, A.; Smreczak, B.; Janusauskaite, D. Ecotoxic effect of phenanthrene on nitrifying bacteria in soils of different properties. J. Environ. Qual. 2007, 36, 1635-1645. [CrossRef]

64. Guo, G.X.; Deng, H.; Qiao, M.; Yao, H.Y.; Zhu, Y.G. Effect of long-term wastewater irrigation on potential denitrification and denitrifying communities in soils at the watershed scale. Environ. Sci. Technol. 2013, 47, 3105-3113. [CrossRef]

65. Spokas, K.A.; Baker, J.M.; Reicosky, D.C. Ethylene: Potential key for biochar amendment impacts. Plant Soil 2010, 333, 443-452. [CrossRef]

66. Wang, C.; Lu, H.; Da, D.; Deng, H.; Strong, P.J.; Wang, H.; Wu, W. Insight into the effects of biochar on manure composting: Evidence supporting the relationship between $\mathrm{N}_{2} \mathrm{O}$ emission and denitrifying community. Environ. Sci. Technol. 2013, 47, 7341-7349. [CrossRef]

67. Mahmood, F.; Khan, I.; Ashraf, U.; Shahzad, T.; Hussain, S.; Shahid, M.; Abid, M.; Ullah, S. Effects of organic and inorganic manures on maize and their residual impact on soil physico-chemical properties. J. Soil Sci. Plant Nutr. 2017, 17, 22-32. [CrossRef]

68. Yang, X.; Zhang, S.; Ju, M.; Liu, L. Preparation and modification of biochar materials and their application in soil remediation. Appl. Sci. 2019, 9, 1365. [CrossRef]

69. Feng, Y.; Xu, Y.; Yu, Y.; Xie, Z.; Lin, X. Mechanisms of biochar decreasing methane emission from Chinese paddy soils. Soil Biol. Biochem. 2012, 46, 80-88. [CrossRef]

70. Karhu, K.; Mattila, T.; Bergström, I.; Regina, K. Biochar addition to agricultural soil increased $\mathrm{CH}_{4}$ uptake and water holding capacity-Results from a short-term pilot field study. Agric. Ecosyst. Environ. 2011, 140, 309-313. [CrossRef]

71. Spokas, K.A.; Reicosky, D.C. Impacts of sixteen different biochars on soil greenhouse gas production. Ann. Environ. Sci. 2009, 3, 179-193.

72. Zhang, A.; Cui, L.; Pan, G.; Li, L.; Hussain, Q.; Zhang, X.; Zheng, J.; Crowley, D. Effect of biochar amendment on yield and methane and nitrous oxide emissions from a rice paddy from Tai Lake plain, China. Agric. Ecosyst. Environ. 2010, 139, 469-475. [CrossRef]

73. Kammann, C.; Ratering, S.; Eckhard, C.; Müller, C. Biochar and hydrochar effects on greenhouse gas (carbon dioxide, nitrous oxide, and methane) fluxes from soils. J. Environ. Qual. 2012, 41, 1052-1066. [CrossRef]

74. Yamato, M.; Okimori, Y.; Wibowo, I.F.; Anshori, S.; Ogawa, M. Effects of the application of charred bark of Acacia mangium on the yield of maize, cowpea and peanut, and soil chemical properties in South Sumatra, Indonesia. Soil Sci. Plant Nutr. 2006, 52, 489-495. [CrossRef]

75. Jeffery, S.; Verheijen, F.G.A.; van der Velde, M.; Bastos, A.C. A quantitative review of the effects of biochar application to soils on crop productivity using meta-analysis. Agric. Ecosyst. Environ. 2011, 144, 175-187. [CrossRef]

76. Semrau, J.D.; DiSpirito, A.A.; Yoon, S. Methanotrophs and copper. FEMS Microbiol. Rev. 2010, 34, 496-531. [CrossRef]

77. Watanabe, A.; Takeda, T.; Kimura, M. Evaluation of origins of $\mathrm{CH}_{4}$ carbon emitted from rice paddies. J. Geophys. Res. Atmos. 1999, 104, 23623-23629. [CrossRef] 
78. Ma, J.; Xu, H.; Yagi, K.; Cai, Z. Methane emission from paddy soils as affected by wheat straw returning mode. Plant Soil 2008, 313, 167-174. [CrossRef]

79. Cui, Y.F.; Jun, M.E.; Wang, Q.X.; Zhang, W.M.; Cheng, X.Y.; Chen, W.F. Effects of straw and biochar addition on soil nitrogen, carbon, and super rice yield in cold waterlogged paddy soils of North China. J. Integr. Agric. 2017, 16, 1064-1074. [CrossRef]

80. Spokas, K.A.; Cantrell, K.B.; Novak, J.M.; Archer, D.W.; Ippolito, J.A.; Collins, H.P.; Boateng, A.A.; Lima, I.M.; Lamb, M.C.; McAloon, A.J.; et al. Biochar: A synthesis of its agronomic impact beyond carbon sequestration. J. Environ. Qual. 2012, 41, 973-989. [CrossRef]

81. Sun, D.; Meng, J.; Liang, H.; Yang, E.; Huang, Y.; Chen, W.; Jiang, L.; Lan, Y.; Zhang, W.; Gao, J. Effect of volatile organic compounds absorbed to fresh biochar on survival of Bacillus mucilaginosus and structure of soil microbial communities. J. Soils Sediments 2015, 15, 271-281. [CrossRef]

82. Walsh, E.; McDonnell, K.P. The influence of added organic matter on soil physical, chemical, and biological properties: A small-scale and short-time experiment using straw. Arch. Agron. Soil Sci. 2012, 58, S201-S205. [CrossRef]

83. Lehmann, J.; Joseph, S. (Eds.) Biochar for Environmental Management: Science, Technology and Implementation; Routledge: London, UK, 2015.

84. Liu, Y.; Lu, H.; Yang, S.; Wang, Y. Impacts of biochar addition on rice yield and soil properties in a cold waterlogged paddy for two crop seasons. Field Crop. Res. 2016, 191, 161-167. [CrossRef]

85. Noguera, D.; Barot, S.; Laossi, K.R.; Cardoso, J.; Lavelle, P.; de Carvalho, M.C. Biochar but not earthworms enhances rice growth through increased protein turnover. Soil Biol. Biochem. 2012, 52, 13-20. [CrossRef]

86. Zhao, L.; Cao, X.; Mašek, O.; Zimmerman, A. Heterogeneity of biochar properties as a function of feedstock sources and production temperatures. J. Hazard. Mater. 2013, 256, 1-9. [CrossRef]

87. Wang, W.; Lai, D.Y.F.; Sardans, J.; Wang, C.; Datta, A.; Pan, T.; Zeng, C.; Bartrons, M.; Penuelas, J. Rice straw incorporation affects global warming potential differently in early vs. late cropping seasons in Southeastern China. Field Crop. Res. 2015, 181, 42-51. [CrossRef]

88. Zhang, X.; Zhou, Z.; Liu, Y.; Xu, X.; Wang, J.; Zhang, H.; Xiong, Z. Net global warming potential and greenhouse gas intensity in rice agriculture driven by high yields and nitrogen use efficiency: A 5-year field study. Biogeosci. Discuss. 2015, 12, 18883-18911. [CrossRef]

89. Wassmann, R.; Butterbach-Bahl, K.; Dobermann, A. Irrigated rice production systems and greenhouse gas emissions: Crop and residue management trends, climate change impacts and mitigation strategies. CAB Rev. Perspect. Agric. Vet. Sci. Nutr. Nat. Resour. 2007. [CrossRef]

90. Zhuang, Q.; Melack, J.M.; Zimov, S.; Walter, K.M.; Butenhoff, C.L.; Khalil, M.A. Global methan emissions from wetlands, rice paddies, and lakes. Eos Trans. Am. Geophys. Union 2009, 90, 37-38. [CrossRef]

91. Vitousek, P.M.; Naylor, R.; Crews, T.; David, M.B.; Drinkwater, L.E.; Holland, E.; Johnes, P.J. Nutrient imbalances in agricultural development. Science 2009, 324, 1519-1520. [CrossRef] [PubMed]

92. Case, S.D.C. Biochar Amendment and Greenhouse Gas Emissions from Agricultural Soils. Ph.D. Thesis, University of Edinburgh, Edinburgh, UK, 2013; pp. 117-122. Available online: https://ethos.bl.uk/ OrderDetails.do?uin=uk.bl.ethos.586427 (accessed on 1 December 2020).

93. Zheng, H.; Huang, H.; Yao, L.; Liu, J.; He, H.; Tang, J. Impacts of rice varieties and management on yield-scaled greenhouse gas emissions from rice fields in China: A meta-analysis. Biogeosciences 2014, 11, 3685. [CrossRef]

94. Xia, L.; Xia, Y.; Ma, S.; Wang, J.; Wang, S.; Zhou, W.; Yan, X. Greenhouse gas emissions and reactive nitrogen releases from rice production with simultaneous incorporation of wheat straw and nitrogen fertilizer. Biogeosciences 2016, 13, 4569-4579. [CrossRef]

95. Richards, M.; Metzel, R.; Chirinda, N.; Ly, P.; Nyamadzawo, G.; Vu, Q.D.; De Neergaard, A.; Oelofse, M.; Wollenberg, E.; Keller, E.; et al. Limits of agricultural greenhouse gas calculators to predict soil $\mathrm{N}_{2} \mathrm{O}$ and $\mathrm{CH}_{4}$ fluxes in tropical agriculture. Sci. Rep. 2016, 6, 26279. [CrossRef]

96. Kritee, K.; Nair, D.; Zavala-Araiza, D.; Proville, J.; Rudek, J.; Adhya, T.K.; Loecke, T.; Esteves, T.; Balireddygari, S.; Dava, O.; et al. High nitrous oxide fluxes from rice indicate the need to manage water for both long-and short-term climate impacts. Proc. Natl. Acad. Sci. USA 2018, 115, 9720-9725. [CrossRef] 
97. Sanchis, E.; Ferrer, M.; Torres, A.G.; Cambra-López, M.; Calvet, S. Effect of water and straw management practices on methane emissions from rice fields: A review through a meta-analysis. Environ. Eng. Sci. 2012, 29, 1053-1062. [CrossRef]

98. Yao, Z.; Du, Y.; Tao, Y.; Zheng, X.; Liu, C.; Lin, S.; Butterbach-Bahl, K. Water-saving ground cover rice production system reduces net greenhouse gas fluxes in an annual rice-based cropping system. Biogeosciences 2014, 11, 6221-6236. [CrossRef]

99. Xu, Y.; Ge, J.; Tian, S.; Li, S.; Nguy-Robertson, A.L.; Zhan, M.; Cao, C. Effects of water-saving irrigation practices and drought resistant rice variety on greenhouse gas emissions from a no-till paddy in the central lowlands of China. Sci. Total Environ. 2015, 505, 1043-1052. [CrossRef] [PubMed]

100. Vo, T.B.T.; Wassmann, R.; Tirol-Padre, A.; Cao, V.; MacDonald, B.; Espaldon, M.V.O.; Sander, B.O. Methane emission from rice cultivation in different agro-ecological zones of the Mekong river delta: Seasonal patterns and emission factors for baseline water management. Soil Sci. Plant Nutr. 2018, 64, 47-58. [CrossRef]

101. Hussain, M.; Farooq, M.; Nawaz, A.; Al-Sadi, A.M.; Solaiman, Z.M.; Alghamdi, S.S.; Ammara, U.; Ok, Y.S.; Siddique, K.H.M. Biochar for crop production: Potential benefits and risks. J. Soils Sediments 2017, 17, 685-716. [CrossRef]

102. Major, J.; Rondon, M.; Molina, D.; Riha, S.J.; Lehmann, J. Maize yield and nutrition during 4 years after biochar application to a Colombian savanna oxisol. Plant Soil 2010, 333, 117-128. [CrossRef]

Publisher's Note: MDPI stays neutral with regard to jurisdictional claims in published maps and institutional affiliations. 